\title{
Postnatal somatic and mental development after periconceptional multivitamin supplementation
}

\author{
Andrew E Czeizel, Márta Dobó
}

\begin{abstract}
The effect of periconceptional multivitamin supplementation on postnatal development was studied in a randomised controlled trial comparing the use of a multivitamin tablet (Elevit Pronatal) with a tablet containing trace elements as part of the Hungarian Optimal Family Planning Programme. Of 4122 liveborn infants, 3356 were examined after the eighth month of life and medical records were obtained for a further 357; thus the total number of infants evaluated was $3713(90 \cdot 1 \%)$. The mortality was not significantly different between the groups receiving the multivitamins $(9 \cdot 6 / 1000)$ and trace elements $(7 \cdot 1 / 1000)$. There was no significant difference in the rates of serious or chronic disorders between the study groups except for atopic dermatitis, which was reported more often in the group receiving multivitamins (15 v four cases). Somatic development (body weight, body length, and head circumference) did not show a significant difference between the two groups. Mental and behavioural development was also similar in the two groups.

(Arch Dis Child 1994; 70: 229-233)
\end{abstract}

Periconceptional supplementation with a multivitamin formulation, including folic acid $^{12}$ or with folic acid alone ${ }^{34}$ can reduce the recurrence of neural tube defects. The Hungarian randomised controlled trial of periconceptional multivitamin (including $0.8 \mathrm{mg}$ folic acid) supplementation indicated (a) a significant reduction of the first occurrence of neural tube defects, ${ }^{5}$ (b) a significantly lower rate of major congenital abnormalities not completely explained by the significant reduction in neural tube defects, ${ }^{6}$ (c) no significant effect on pregnancy outcomes (different types of fetal death, proportion of low birthweight newborns and preterm births) (A E Czeizel,

Department of Human Genetics and

Teratology, National Institute of Hygiene WHO Collaborating Centre for the

Community Control of Hereditary Diseases,

Budapest, Hungary

A E Czeizel

M Dobó

Correspondence to:

Dr A E Czeizel, H-1966

Budapest, OKI Gyáli út 2-6, Hungary.

Accepted 25 October 1993 those on postnatal somatic and mental development. In one UK study, 96 children aged 2-5 years and 91 children aged 7-10 years were assessed clinically for somatic and mentalbehavioural development after periconceptional supplementation with Pregnavit Forte $\mathrm{F}^{8}$ This study group had no appropriate control, however. At age 7-10 years, the girls were considerably taller than expected. Health, auditory, visual, and developmental status were no different from the general population. None showed a major behaviour disorder but worries, fussiness, and fearfulness were over represented.

The objective of the work reported here is to examine the developmental effects of periconceptional multivitamin supplementation in the children born during the Hungarian randomised controlled trial. ${ }^{5-7}$

\section{Subjects and methods}

The Hungarian Optimal Family Planning Programme (HOFPP) provides periconceptional care for women and their partners. The randomised controlled trial of periconceptional multivitamins as opposed to trace element supplementation was incorporated into the HOFPP. The criteria for participation and the use of full, partial, or no supplementation, the method of randomisation and tablet supply for at least one month before and two months after conception and the components of the 'multivitamin' (Elevit Pronatal) including $0.8 \mathrm{mg}$ folic acid and 'trace elements' have been presented elsewhere. ${ }^{56}$ Women were referred to prenatal care clinics at the 12th week of pregnancy. They were asked to send us their HOFPP certificate about their pregnancy outcome and to visit us with their infants after they were 8 months old.

\section{FIRST FOLLOW UP}

Parents of infants born within the HOFPP were reminded by telephone or letter to attend for an examination of their infants at about the eighth month of life. After reviewing medical records about previously diagnosed congenital anomalies and diseases, treatments, and operations, the examination included (a) a determination of somatic growth by anthropometric measurements, (b) a clinical examination, and (c) the assessment of mental and behavioural development. These examinations were performed blind by an anthropometrist, two paediatricians, and two psychologists. Mental development was measured by the Popper-Szondy functional development test ${ }^{9} 10$ addition to the obvious decrease in medical costs. Because of the expected widespread recommendation and the use of this method, its effects should be examined carefully, including 
Table 1 Database of infants studied

\begin{tabular}{|c|c|c|c|}
\hline Groups & $\begin{array}{l}\text { No of } \\
\text { live } \\
\text { births }\end{array}$ & $\begin{array}{l}\text { No (\%) of } \\
\text { infants } \\
\text { examined }\end{array}$ & $\begin{array}{l}\text { No (\%) of } \\
\text { infants } \\
\text { evaluated }\end{array}$ \\
\hline \multicolumn{4}{|c|}{ Multivitamin supplementation } \\
\hline Full course & 1487 & $1274(85 \cdot 7)$ & $1413(95 \cdot 0)$ \\
\hline Partial course & 412 & $354(85.9)$ & $396(96 \cdot 1)$ \\
\hline Subtotal & 1899 & $1628(85 \cdot 7)$ & $1809(95 \cdot 3)$ \\
\hline No supplement & 191 & $67(35 \cdot 1)$ & $67(35 \cdot 1)$ \\
\hline Total & 2090 & $1695(81 \cdot 1)$ & $1876(89 \cdot 8)$ \\
\hline \multicolumn{4}{|c|}{ Trace element supplementation } \\
\hline Full course & 1482 & $1270(85 \cdot 7)$ & $1395(94 \cdot 1)$ \\
\hline Partial course & 401 & $336(83 \cdot 8)$ & $387(96 \cdot 5)$ \\
\hline Subtotal & 1883 & $1606(85 \cdot 3)$ & $1782(94 \cdot 6)$ \\
\hline No supplement & 149 & $55(36.9)$ & $55(36.9)$ \\
\hline Total & 2032 & $1661(81 \cdot 7)$ & $1837(90 \cdot 4)$ \\
\hline
\end{tabular}

until the end of 1989 (after this date mental development was not measured). This test assesses 10 variables of motor, verbal, and social development and the cumulative scores are evaluated. Behavioural development was examined by using the Budapest developmental test. ${ }^{11}$ This test uses five indices: fine motor and gross motor development, verbal development, social competence, and social skills. The developmental quotient (DQ) can be calculated using the first four indices, whereas the fifth index has an independent function similar to the Vineland social maturity scale. These two tests were used to measure the first 2000 infants of the HOFPP.

If families did not attend for examination of their infants, we repeated the invitation to all except the unsupplemented group. If there was no response we contacted the paediatrician of the infants studied and obtained a case history, particularly data on congenital anomalies diagnosed after birth and death. We have already reported the data on congenital abnormalities. ${ }^{6}$

Table 2 Demographic factors in groups studied

\begin{tabular}{|c|c|c|c|}
\hline Groups & $\begin{array}{l}\text { Mean (SD) } \\
\text { maternal } \\
\text { age } \\
\text { (years) }\end{array}$ & $\begin{array}{l}\text { Proportion } \\
\text { of } \\
\text { primiparae } \\
(\%)\end{array}$ & $\begin{array}{l}\text { Proportion } \\
\text { of women } \\
\text { with } 13 \text { or } \\
\text { more years } \\
\text { of education } \\
(\%)\end{array}$ \\
\hline \multicolumn{4}{|c|}{ Multivitamin supplementation } \\
\hline Full course & $26 \cdot 9(3 \cdot 3)$ & $94 \cdot 7$ & $64 \cdot 5$ \\
\hline Partial course & $26 \cdot 8(3 \cdot 6)$ & $93 \cdot 5$ & $62 \cdot 6$ \\
\hline Subtotal & $26.9(3.4)$ & $94 \cdot 5$ & $64 \cdot 1$ \\
\hline No supplement & $25.9(3.1)$ & $97 \cdot 7$ & $56 \cdot 8$ \\
\hline \multicolumn{4}{|c|}{ Trace element supplementation } \\
\hline Full course & $26.9(3.4)$ & 93.4 & $64 \cdot 4$ \\
\hline Partial course & $26.4(3.4)$ & $94 \cdot 8$ & $62 \cdot 2$ \\
\hline Subtotal & $26 \cdot 8(3 \cdot 4)$ & $93 \cdot 7$ & $64 \cdot 2$ \\
\hline No supplement & $26 \cdot 1(3 \cdot 5)$ & $97 \cdot 0$ & $58 \cdot 7$ \\
\hline
\end{tabular}

Statistical evaluation included the two tailed $\chi^{2}$ test and Mann-Whitney $U$ test.

\section{Results}

The randomisation code was broken at the end of 1991 . Of 4753 women with confirmed pregnancy, the outcomes could not be ascertained in $49(1 \%)$. Of 4704 evaluated pregnancies, $4122(87 \cdot 6 \%)$ ended in a live birth and they are the subject of the postnatal developmental study. Table 1 gives the numbers of infants examined or evaluated. The proportion of evaluated and examined infants after the age of 8 months was almost the same in the groups fully and partially supplemented with multivitamins and trace elements. It was significantly lower in unsupplemented groups due to lower compliance and our reduced effort to follow up these infants.

Demographic factors such as maternal age and the proportion of primiparae and of higher educated women as an indicator of socioeconomic status were not significantly different between the groups fully and partially supplemented with multivitamins and trace elements (table 2). The high proportion of primiparae is explained by the fact that only women with no previous wanted pregnancy were eligible in the first four years of the HOFPP.

The occurrence of serious and/or chronic diseases, the results of anthropometric measurements, and the mental-behavioural tests are described here only in infants examined personally. The data from the groups fully and partially supplemented with multivitamins are combined in this paper because the variables studied did not show significant differences between these groups. Because of the absence or brief use of supplements and observed differences in demographic factors (women were younger with a higher proportion of primiparae and a lower proportion who had received higher education) as well as our reduced efforts in follow up, unsupplemented groups were excluded from the analysis of case history, somatic and mental-behavioural development. We followed a similar method in the trace element group; thus fully and partially supplemented groups are combined in the trace element group.

The age distribution of infants at the time of examination (table 3 ) did not show significant

Table 3 Age distribution of infants at the time of investigation

\begin{tabular}{|c|c|c|c|c|c|c|}
\hline \multirow[b]{2}{*}{ Age (months) } & \multicolumn{3}{|c|}{ No $(\%)$ receiving multivitamin supplementation } & \multicolumn{3}{|c|}{ No (\%) receiving trace element supplementation } \\
\hline & $\begin{array}{l}\text { Boys } \\
(n=812)\end{array}$ & $\begin{array}{l}\text { Girls } \\
(n=816)\end{array}$ & $\begin{array}{l}\text { Total } \\
(n=1628)\end{array}$ & $\begin{array}{l}\text { Boys } \\
(n=826)\end{array}$ & $\begin{array}{l}\text { Girls } \\
(n=780)\end{array}$ & $\begin{array}{l}\text { Total } \\
(n=1606)\end{array}$ \\
\hline $\begin{array}{l}8 \\
9 \\
10 \\
11 \\
12 \\
13 \\
14 \\
15 \\
16 \\
\geqslant 17 \\
\text { Mean }(95 \% \text { confidence } \\
\text { interval) } \\
\text { Subtotal` }\end{array}$ & $\begin{array}{l}54(6 \cdot 6) \\
80(9 \cdot 9) \\
162(20 \cdot 0) \\
206(25 \cdot 4) \\
134(16 \cdot 5) \\
74(9 \cdot 1) \\
54(6 \cdot 7) \\
24(3 \cdot 0) \\
10(1 \cdot 2) \\
14(1 \cdot 7) \\
11(10 \cdot 88 \text { to } \\
11 \cdot 22) \\
798(98 \cdot 3)\end{array}$ & $\begin{array}{l}43(5 \cdot 3) \\
93(11 \cdot 4) \\
166(20 \cdot 3) \\
194(23 \cdot 8) \\
143(17 \cdot 5) \\
65(8 \cdot 0) \\
53(6 \cdot 5) \\
35(4 \cdot 3) \\
10(1 \cdot 2) \\
14(1 \cdot 7) \\
11(10 \cdot 86 \text { to } \\
11 \cdot 14) \\
802(98 \cdot 3)\end{array}$ & $\begin{array}{c}97(6 \cdot 0) \\
173(10 \cdot 6) \\
328(20 \cdot 1) \\
400(24 \cdot 6) \\
277(17 \cdot 0) \\
139(8 \cdot 5) \\
107(6 \cdot 6) \\
59(3 \cdot 6) \\
20(1 \cdot 2) \\
28(1 \cdot 7) \\
11(10 \cdot 90 \text { to } \\
11 \cdot 10) \\
1600(98 \cdot 3)\end{array}$ & $\begin{array}{c}34(4 \cdot 1) \\
84(10 \cdot 2) \\
159(19 \cdot 2) \\
220(26 \cdot 6) \\
136(16 \cdot 5) \\
73(8 \cdot 8) \\
67(8 \cdot 1) \\
31(3 \cdot 8) \\
5(0 \cdot 6) \\
17(2 \cdot 1) \\
11(10 \cdot 86 \text { to } \\
11 \cdot 14) \\
809(97 \cdot 9)\end{array}$ & $\begin{array}{c}44(5 \cdot 6) \\
73(9 \cdot 4) \\
163(20 \cdot 9) \\
196(25 \cdot 1) \\
119(15 \cdot 3) \\
76(9 \cdot 7) \\
60(7 \cdot 7) \\
29(3 \cdot 7) \\
5(0 \cdot 6) \\
15(1 \cdot 9) \\
11(10 \cdot 86 \text { to } \\
11 \cdot 14) \\
764(97 \cdot 9)\end{array}$ & $\begin{array}{c}78(4 \cdot 9) \\
157(9 \cdot 8) \\
322(20 \cdot 0) \\
416(25 \cdot 9) \\
255(15 \cdot 9) \\
149(9 \cdot 3) \\
127(7 \cdot 9) \\
60(3 \cdot 7) \\
10(0 \cdot 6) \\
32(2 \cdot 0) \\
11(10 \cdot 90 \text { to } \\
11 \cdot 10) \\
1573(97 \cdot 9)\end{array}$ \\
\hline
\end{tabular}

`Total infants aged 8-16 months only. 
Table 4 Causes of postnatal mortality (intention to treat analysis)

\begin{tabular}{lcc}
\hline Cause & $\begin{array}{l}\text { No receiving } \\
\text { multivitamin } \\
\text { supplementation }\end{array}$ & $\begin{array}{l}\text { No receiving } \\
\text { trace element } \\
\text { supplementation }\end{array}$ \\
\hline Very low birth weight & 6 & 4 \\
Congenital abnormality & $4^{\star}$ & $4 \dagger$ \\
Respiratory distress & 4 & 3 \\
Streptococcal sepsis & 2 & 2 \\
Sudden infant death & 1 & 0 \\
syndrome & 1 & 0 \\
Cerebellar tumour & $18(9 \cdot 59)$ & $13(7 \cdot 08)$ \\
Total (rate/100) &
\end{tabular}

^Left heart hypoplasia, Alagille's syndrome, collodion infant, unidentified multiple congenital abnormality.

†Spina bifida cystica, congenital hydrocephalus, transposition of great vessels, left heart hypoplasia.

Table 5 Distribution of serious and chronic disorders in the study groups

\begin{tabular}{lll}
\hline Disorder & $\begin{array}{l}\text { No receiving } \\
\text { multivitamin } \\
\text { supplementation }\end{array}$ & $\begin{array}{l}\text { No receiving } \\
\text { trace element } \\
\text { supplementation }\end{array}$ \\
\hline Injury to brachial plexus & 0 & 1 \\
Epilepsy & 1 & 3 \\
Infantile hemiplegia & 1 & 3 \\
Infantile spasms & 4 & 2 \\
Asthma & 4 & 1 \\
Wheezy bronchitis & 7 & 3 \\
Atopic dermatitis & 15 & 4 \\
Food allergy & 7 & 8 \\
Pneumonia & 10 & 10 \\
Recurrent urinary infection & 15 & 16 \\
Total (rate/1000) & $64(39 \cdot 3)$ & $53(33 \cdot 0)$ \\
\hline
\end{tabular}

differences between the multivitamin and trace element groups $\left(\chi^{2}{ }_{8}=9 \cdot 30 ; p=0 \cdot 32\right)$. The mean age was 11 months in the two groups with a range of 8-21 months. Sex distribution was also similar in the two study groups. Thus it is possible to compare the data of the multivitamin and trace element groups.

The postnatal mortality was calculated for all evaluated infants (table 4 ). The mortality was $9 \cdot 6$ and $7 \cdot 1$ per 1000 infants in the multivitamin and trace element groups, respectively $\left(\chi^{2}{ }_{1}=0 \cdot 71 ; p=0 \cdot 40\right)$.

Serious or chronic disorders were evaluated on the basis of case history or personal examination, or both, in the multivitamin and trace element groups (table 5). The usual acute and non-severe childhood disorders were not considered. The total rate of disorders did not differ significantly between the two study groups $\left(\chi^{2}{ }_{1}=0.92 ; p=0.34\right)$. There was no significant difference in disorders except for atopic dermatitis, which showed a higher rate in the multivitamin group $\left(\chi^{2}{ }_{1}=6 \cdot 26\right.$; $p=0.012$ ). Of these 15 infants, however, four had a parent with atopic dermatitis. The multivitamin group also showed an excess of asthma and wheezy bronchitis. If these three disorders, which are closely related, are combined, there are 26 children in the multivitamin group and eight in the trace element group. The difference is highly significant $\left(\chi_{1}^{2}=9.39\right.$; $\mathrm{p}=0.0022$ ). Of these 26 subjects, six had a positive family history in the multivitamin group. Of eight controls, none had parents with asthma or eczema, or both, although two parents of the controls had a drug allergy.

In the evaluation of anthropometric data we analysed the distribution and means to give the confidence intervals of the absolute values (table 3). Infants over the age of 16 months were excluded due to their small number and wide uneven range. The observed anthropometric data showed a slight deviation from the expected Gaussian normal distribution, probably due to the uneven age distribution.

The distributions of body weight $\left(\chi^{2}{ }_{7}=5.03\right.$; $\mathrm{p}=0.66)$ (table 6$)$, body length $\left(\chi^{2}{ }_{6}=11 \cdot 18\right.$; $\mathrm{p}=0.08$ ) (table 7), and head circumference $\left(\chi_{1}^{2}=7 \cdot 18 ; p=0 \cdot 21\right)$ (table 8) did not show any significant differences between the multivitamin and trace element groups. Means were the same or nearly similar in the study groups. Thus the results of statistical analyses are not detailed further.

The distributions of mental development measured by the Popper-Szondy functional

Table 6 Body weight distribution: mean and SD in the study groups at age 8-16 months

\begin{tabular}{|c|c|c|c|c|c|c|}
\hline \multirow[b]{2}{*}{$\begin{array}{l}\text { Body weight } \\
\text { group (kg) }\end{array}$} & \multicolumn{3}{|c|}{ No (\%) receiving multivitamin supplementation } & \multicolumn{3}{|c|}{ No (\%) receiving trace element supplementation } \\
\hline & $\begin{array}{l}\text { Boys } \\
(n=798)\end{array}$ & $\begin{array}{l}\text { Girls } \\
(n=802)\end{array}$ & $\begin{array}{l}\text { Total } \\
(n=1600)\end{array}$ & $\begin{array}{l}\text { Boys } \\
(n=809)\end{array}$ & $\begin{array}{l}\text { Girls } \\
(n=764)\end{array}$ & $\begin{array}{l}\text { Total } \\
(n=1573)\end{array}$ \\
\hline $\begin{array}{l}6 \cdot 0-6 \cdot 9 \\
7 \cdot 0-7 \cdot 9 \\
8 \cdot 0-8 \cdot 9 \\
9 \cdot 0-9 \cdot 9 \\
10 \cdot 0-10 \cdot 9 \\
11 \cdot 0-11 \cdot 9 \\
12 \cdot 0-12 \cdot 9 \\
\geqslant 13 \cdot 0 \\
\text { Mean (95\% confidence } \\
\text { interval) }\end{array}$ & $\begin{array}{l}1(0 \cdot 1) \\
27(3 \cdot 4) \\
121(15 \cdot 2) \\
223(27 \cdot 9) \\
229(28 \cdot 7) \\
123(15 \cdot 4) \\
59(7 \cdot 4) \\
15(1 \cdot 9) \\
9 \cdot 96(9 \cdot 88 \text { to } \\
10 \cdot 04)\end{array}$ & $\begin{array}{l}6(0 \cdot 7) \\
66(8 \cdot 2) \\
204(25 \cdot 4) \\
275(34 \cdot 3) \\
165(20 \cdot 6) \\
61(7 \cdot 6) \\
16(2 \cdot 0) \\
9(1 \cdot 1) \\
9 \cdot 34(9 \cdot 26 \text { to } \\
9 \cdot 42)\end{array}$ & $\begin{array}{l}7(0 \cdot 4) \\
93(5 \cdot 8) \\
325(20 \cdot 3) \\
498(31 \cdot 1) \\
394(24 \cdot 6) \\
184(11 \cdot 5) \\
75(4 \cdot 7) \\
24(1 \cdot 5) \\
9 \cdot 65(9 \cdot 59 \text { to } \\
9 \cdot 71)\end{array}$ & $\begin{array}{c}2(0 \cdot 2) \\
22(2 \cdot 7) \\
103(12 \cdot 7) \\
248(30 \cdot 7) \\
266(32 \cdot 9) \\
100(12 \cdot 4) \\
54(6 \cdot 7) \\
14(1 \cdot 7) \\
10 \cdot 01(9 \cdot 93 \text { to } \\
10 \cdot 09)\end{array}$ & $\begin{array}{l}3(0 \cdot 4) \\
71(9 \cdot 3) \\
223(29 \cdot 2) \\
227(29 \cdot 7) \\
161(21 \cdot 1) \\
54(7 \cdot 1) \\
19(2 \cdot 5) \\
6(0 \cdot 8) \\
9 \cdot 30(9 \cdot 22 \text { to } \\
9 \cdot 38)\end{array}$ & $\begin{array}{l}5(0 \cdot 3) \\
93(5 \cdot 9) \\
326(20 \cdot 7) \\
475(30 \cdot 2) \\
427(27 \cdot 1) \\
154(9 \cdot 8) \\
73(4 \cdot 6) \\
20(1 \cdot 3) \\
9 \cdot 67(9 \cdot 61 \text { to } \\
9 \cdot 73)\end{array}$ \\
\hline
\end{tabular}

Table 7 Body length distribution: mean and SD in the study groups at age 8-16 months

\begin{tabular}{|c|c|c|c|c|c|c|}
\hline \multirow[b]{2}{*}{$\begin{array}{l}\text { Body length } \\
\text { group }(\mathrm{cm})\end{array}$} & \multicolumn{3}{|c|}{ No (\%) receiving multivitamin supplementation } & \multicolumn{3}{|c|}{ No (\%) receiving trace element supplementation } \\
\hline & $\begin{array}{l}\text { Boys } \\
(n=798)\end{array}$ & $\begin{array}{l}\text { Girls } \\
(n=802)\end{array}$ & $\begin{array}{l}\text { Total } \\
(n=1600)\end{array}$ & $\begin{array}{l}\text { Boys } \\
(n=809)\end{array}$ & $\begin{array}{l}\text { Girls } \\
(n=764)\end{array}$ & $\begin{array}{l}\text { Total } \\
(n=1573)\end{array}$ \\
\hline $\begin{array}{l}\leqslant 64 \\
65-69 \\
70-74 \\
75-79 \\
80-84 \\
85-89 \\
\geqslant 90 \\
\text { Mean (95\% confidence } \\
\text { interval) }\end{array}$ & $\begin{array}{l}0 \\
24(3 \cdot 0) \\
237(29 \cdot 7) \\
340(42 \cdot 6) \\
172(21 \cdot 6) \\
19(2 \cdot 4) \\
6(0 \cdot 7) \\
77(76 \cdot 72 \text { to } \\
77 \cdot 28)\end{array}$ & $\begin{array}{c}2(0 \cdot 2) \\
60(7 \cdot 5) \\
299(37 \cdot 3) \\
307(38 \cdot 3) \\
112(14 \cdot 0) \\
14(1 \cdot 7) \\
8(1 \cdot 0) \\
75(74 \cdot 64 \text { to } \\
75 \cdot 36)\end{array}$ & $\begin{array}{c}2(0 \cdot 1) \\
84(5 \cdot 3) \\
536(33 \cdot 5) \\
647(40 \cdot 4) \\
284(17 \cdot 7) \\
33(2 \cdot 1) \\
14(0 \cdot 9) \\
76(75 \cdot 80 \text { to } \\
76 \cdot 20)\end{array}$ & $\begin{array}{c}0 \\
15(1 \cdot 9) \\
229(28 \cdot 3) \\
354(43 \cdot 8) \\
166(20 \cdot 5) \\
40(4 \cdot 9) \\
5(0 \cdot 6) \\
77(76 \cdot 72 \text { to } \\
77 \cdot 28)\end{array}$ & $\begin{array}{c}3(0 \cdot 4) \\
61(8 \cdot 0) \\
313(41 \cdot 0) \\
266(34 \cdot 8) \\
98(12 \cdot 8) \\
20(2 \cdot 6) \\
3(0 \cdot 4) \\
75(74 \cdot 72 \text { to } \\
75 \cdot 28)\end{array}$ & $\begin{array}{c}3(0 \cdot 2) \\
76(4 \cdot 8) \\
542(34 \cdot 4) \\
620(39 \cdot 4) \\
264(16 \cdot 8) \\
60(3 \cdot 8) \\
8(0 \cdot 5) \\
76(75 \cdot 74 \text { to } \\
76 \cdot 26)\end{array}$ \\
\hline
\end{tabular}


Table 8 Head circumference distribution: mean and SD in the study groups at age 8-16 months

\begin{tabular}{|c|c|c|c|c|c|c|}
\hline \multirow[b]{2}{*}{$\begin{array}{l}\text { Head circumference } \\
(\mathrm{mm})\end{array}$} & \multicolumn{3}{|c|}{ No (\%) receiving multivitamin supplementation } & \multicolumn{3}{|c|}{ No (\%) receiving trace element supplementation } \\
\hline & $\begin{array}{l}\text { Boys } \\
(n=798)\end{array}$ & $\begin{array}{l}\text { Girls } \\
(n=802)\end{array}$ & $\begin{array}{l}\text { Total } \\
(n=1600)\end{array}$ & $\begin{array}{l}\text { Boys } \\
(n=809)\end{array}$ & $\begin{array}{l}\text { Girls } \\
(n=764)\end{array}$ & $\begin{array}{l}\text { Total } \\
(n=1573)\end{array}$ \\
\hline $\begin{array}{l}\leqslant 409 \\
410-419 \\
420-429 \\
430-439 \\
440-449 \\
450-459 \\
460-469 \\
470-479 \\
480-489 \\
490-499 \\
500-509 \\
\geqslant 510 \\
\text { Mean (95\% confidence } \\
\text { interval) }\end{array}$ & $\begin{array}{c}1(0 \cdot 1) \\
3(0 \cdot 4) \\
6(0 \cdot 7) \\
13(1 \cdot 6) \\
69(8 \cdot 6) \\
164(20 \cdot 6) \\
229(28 \cdot 7) \\
186(23 \cdot 3) \\
98(12 \cdot 3) \\
24(3 \cdot 1) \\
4(0 \cdot 5) \\
1(0 \cdot 1) \\
463(462 \cdot 00 \text { to } \\
464 \cdot 00)\end{array}$ & $\begin{array}{c}2(0 \cdot 3) \\
5(0 \cdot 6) \\
10(1 \cdot 3) \\
60(7 \cdot 5) \\
153(19 \cdot 1) \\
216(26 \cdot 9) \\
220(27 \cdot 4) \\
94(11 \cdot 7) \\
34(4 \cdot 2) \\
6(0 \cdot 8) \\
1(0 \cdot 1) \\
1(0 \cdot 1) \\
454(453 \cdot 02 \text { to } \\
454.98)\end{array}$ & $\begin{array}{c}3(0 \cdot 2) \\
8(0 \cdot 5) \\
16(1 \cdot 0) \\
73(4 \cdot 6) \\
222(13 \cdot 9) \\
380(23 \cdot 7) \\
449(28 \cdot 1) \\
280(17 \cdot 5) \\
132(8 \cdot 2) \\
30(1 \cdot 9) \\
5(0 \cdot 3) \\
2(0 \cdot 1) \\
458(457 \cdot 24 \text { to } \\
458 \cdot 76)\end{array}$ & $\begin{array}{c}1(0 \cdot 1) \\
1(0 \cdot 1) \\
2(0 \cdot 3) \\
13(1 \cdot 6) \\
64(7 \cdot 9) \\
151(18 \cdot 7) \\
255(31 \cdot 5) \\
192(23 \cdot 7) \\
88(10 \cdot 9) \\
32(4 \cdot 0) \\
8(1 \cdot 0) \\
2(0 \cdot 2) \\
463(462 \cdot 02 \text { to } \\
463.98)\end{array}$ & $\begin{array}{c}0 \\
2(0 \cdot 3) \\
12(1 \cdot 6) \\
62(8 \cdot 1) \\
156(20 \cdot 4) \\
245(32 \cdot 1) \\
178(23 \cdot 3) \\
77(10 \cdot 1) \\
25(3 \cdot 3) \\
6(0 \cdot 8) \\
1(0 \cdot 1) \\
0(0 \cdot 0) \\
453(452 \cdot 06 \text { to } \\
453 \cdot 94)\end{array}$ & $\begin{array}{c}1(0 \cdot 1) \\
3(0 \cdot 2) \\
14(0 \cdot 9) \\
75(4 \cdot 8) \\
220(14 \cdot 0) \\
396(25 \cdot 2) \\
433(27 \cdot 5) \\
269(17 \cdot 1) \\
113(7 \cdot 2) \\
38(2 \cdot 4) \\
9(0 \cdot 6) \\
2(0 \cdot 1) \\
458(457 \cdot 30 \text { to } \\
458 \cdot 70)\end{array}$ \\
\hline
\end{tabular}

developmental test did not show a significant difference between the multivitamin and trace element groups $\left(\chi^{2}{ }_{4}=2 \cdot 47 ; p=0 \cdot 65\right)$ (table 9). The means were the same in both study groups. Finally, the behavioural development of 1540 infants was tested (children who were not completely healthy at the time of examination were not studied). The distributions $\left(\chi_{6}^{2}=0.48 ; p=5.49\right)$ and means of the $\mathrm{DQ}$, based on the Budapest developmental test, were nearly the same in the study groups (table 10). The distributions of the social skill quotient (SSQ, table 11) did not show any differences between the two study groups $\left(\chi^{2}{ }_{5}=2 \cdot 64 ; \mathrm{p}=0.76\right)$ and the means were the same.

\section{Discussion}

The nutritional status of Hungarian women in the preconceptional and gestational periods is good: their mean energy intake is estimated to be 10230 and $11238-12727 \mathrm{~kJ} /$ day, respectively (it is $8917 \mathrm{~kJ}$ in non-pregnant women aged 19-34 years). In the preconceptional period and during pregnancy their daily intake of folic acid is about 158.5 and $172-188 \mu \mathrm{g}$, respectively (A E Czeizel, E Susánszky, unpublished data).
We analysed infant development after the age of 8 months after maternal enrolment in the randomised controlled trial of periconceptional multivitamin/trace element supplementation. We expected to see no effect. Supplements were taken for a few months before conception and in the first trimester of pregnancy. Vitamins or multivitamins are generally prescribed for pregnant women after the 10th week of gestation at prenatal care clinics and over the counter vitamins are often used during the second and third trimesters. In Hungary about $65 \%$ of pregnant women used folic acid and about $6 \%$ of them multivitamins in 1988-92 (A E Czeizel, E Susánszky, unpublished data).

The mortality was not significantly different $(p=0 \cdot 40)$ between the multivitamin $(9 \cdot 6 / 1000)$ and trace element $(7 \cdot 1 / 1000)$ groups. Infant mortality in Hungary was $17 \cdot 7 / 1000$ live births during the study period. Thus a significantly lower infant mortality was found in the two study groups of the HOFPP.

The occurrence of reported and documented serious or chronic diseases in infants was nearly the same in the two groups, with two exceptions. Atopic dermatitis was reported more often in infants of women receiving multivitamin supplementation than in control

Table 9 Distribution of scores of the Popper-Szondy functional developmental test: mean and SD in the study groups

\begin{tabular}{|c|c|c|c|c|c|c|}
\hline \multirow[b]{2}{*}{ Score } & \multicolumn{3}{|c|}{ No (\%) receiving multivitamin supplementation } & \multicolumn{3}{|c|}{ No (\%) receiving trace element supplementation } \\
\hline & $\begin{array}{l}\text { Boys } \\
(n=531)\end{array}$ & $\begin{array}{l}\text { Girls } \\
(n=513)\end{array}$ & $\begin{array}{l}\text { Total } \\
(n=1044)\end{array}$ & $\begin{array}{l}\text { Boys } \\
(n=533)\end{array}$ & $\begin{array}{l}\text { Girls } \\
(n=505)\end{array}$ & $\begin{array}{l}\text { Total } \\
(n=1038)\end{array}$ \\
\hline $\begin{array}{l}85-89 \\
90-99 \\
100-109 \\
110-119 \\
\geqslant 120 \\
\text { Mean (95\% confidence } \\
\text { interval) }\end{array}$ & $\begin{array}{c}8(1 \cdot 5) \\
101(19 \cdot 0) \\
169(31 \cdot 8) \\
159(29 \cdot 9) \\
94(17 \cdot 7) \\
109(108 \cdot 14 \text { to } \\
109 \cdot 86)\end{array}$ & $\begin{array}{c}4(0 \cdot 8) \\
94(18 \cdot 3) \\
148(28 \cdot 9) \\
157(30 \cdot 6) \\
110(21 \cdot 4) \\
110(109 \cdot 12 \text { to } \\
110 \cdot 88)\end{array}$ & $\begin{array}{l}12(1 \cdot 1) \\
195(18 \cdot 7) \\
317(30 \cdot 4) \\
316(30 \cdot 3) \\
204(19 \cdot 5) \\
110(109 \cdot 38 \text { to } \\
110 \cdot 62)\end{array}$ & $\begin{array}{c}5(0 \cdot 9) \\
105(19 \cdot 7) \\
184(34 \cdot 5) \\
156(29 \cdot 3) \\
83(15 \cdot 6) \\
109(108 \cdot 14 \text { to } \\
109 \cdot 86)\end{array}$ & $\begin{array}{c}4(0 \cdot 8) \\
72(14 \cdot 3) \\
144(28 \cdot 5) \\
178(35 \cdot 2) \\
107(21 \cdot 2) \\
111(110 \cdot 12 \text { to } \\
111 \cdot 88)\end{array}$ & $\begin{array}{c}9(0 \cdot 9) \\
177(17 \cdot 0) \\
328(31 \cdot 6) \\
334(32 \cdot 2) \\
190(18 \cdot 3) \\
110(109 \cdot 38 \text { to } \\
110 \cdot 62)\end{array}$ \\
\hline
\end{tabular}

Table 10 Distribution of $D Q$ of the Budapest developmental test: mean and SD in the study groups

\begin{tabular}{|c|c|c|c|c|c|c|}
\hline \multirow[b]{2}{*}{$D Q$} & \multicolumn{3}{|c|}{ No (\%) receiving multivitamin supplementation } & \multicolumn{3}{|c|}{ No (\%) receiving trace element supplementation } \\
\hline & $\begin{array}{l}\text { Boys } \\
(n=395)\end{array}$ & $\begin{array}{l}\text { Girls } \\
(n=389)\end{array}$ & $\begin{array}{l}\text { Total } \\
(n=784)\end{array}$ & $\begin{array}{l}\text { Boys } \\
(n=400)\end{array}$ & $\begin{array}{l}\text { Girls } \\
(n=356)\end{array}$ & $\begin{array}{l}\text { Total } \\
(n=756)\end{array}$ \\
\hline $\begin{array}{l}\leqslant 24 \\
25-29 \\
30-34 \\
35-39 \\
40-44 \\
45-49 \\
\geqslant 50 \\
\text { Mean (95\% confidence } \\
\text { interval) }\end{array}$ & $\begin{array}{c}12(3 \cdot 0) \\
44(11 \cdot 1) \\
142(35 \cdot 9) \\
131(33 \cdot 2) \\
48(12 \cdot 2) \\
11(2 \cdot 8) \\
7(1 \cdot 8) \\
35(34 \cdot 50 \text { to } \\
35 \cdot 50)\end{array}$ & $\begin{array}{c}11(2 \cdot 8) \\
49(12 \cdot 6) \\
131(33 \cdot 7) \\
130(33 \cdot 4) \\
49(12 \cdot 6) \\
9(2 \cdot 3) \\
10(2 \cdot 6) \\
36(35 \cdot 50 \text { to } \\
36 \cdot 50)\end{array}$ & $\begin{array}{c}23(2 \cdot 9) \\
93(11 \cdot 9) \\
273(34 \cdot 8) \\
261(33 \cdot 3) \\
97(12 \cdot 4) \\
20(2 \cdot 5) \\
17(2 \cdot 2) \\
35(34 \cdot 64 \text { to } \\
35 \cdot 36)\end{array}$ & $\begin{array}{c}13(3 \cdot 3) \\
39(9 \cdot 7) \\
156(39 \cdot 0) \\
140(35 \cdot 0) \\
35(8 \cdot 7) \\
10(2 \cdot 5) \\
7(1 \cdot 8) \\
35(34 \cdot 50 \text { to } \\
35 \cdot 50)\end{array}$ & $\begin{array}{c}7(2 \cdot 0) \\
32(9 \cdot 0) \\
128(35 \cdot 9) \\
121(34 \cdot 0) \\
43(12 \cdot 1) \\
15(4 \cdot 2) \\
10(2 \cdot 8) \\
36(35 \cdot 48 \text { to } \\
36 \cdot 52)\end{array}$ & $\begin{array}{c}20(2 \cdot 6) \\
71(9 \cdot 4) \\
284(37 \cdot 6) \\
261(34 \cdot 5) \\
78(10 \cdot 3) \\
25(3 \cdot 3) \\
17(2 \cdot 3) \\
36(35 \cdot 64 \text { to } \\
(36 \cdot 36)\end{array}$ \\
\hline
\end{tabular}


Table 11 Distribution of SSQ of the Budapest developmental test: mean and SD in the study groups

\begin{tabular}{|c|c|c|c|c|c|c|}
\hline \multirow[b]{2}{*}{$S S Q$} & \multicolumn{3}{|c|}{ No (\%) receiving multivitamin supplementation } & \multicolumn{3}{|c|}{ No $(\%)$ receiving trace element supplementation } \\
\hline & $\begin{array}{l}\text { Boys } \\
(n=395)\end{array}$ & $\begin{array}{l}\text { Girls } \\
(n=389)\end{array}$ & $\begin{array}{l}\text { Total } \\
(n=784)\end{array}$ & $\begin{array}{l}\text { Boys } \\
(n=400)\end{array}$ & $\begin{array}{l}\text { Girls } \\
(n=356)\end{array}$ & $\begin{array}{l}\text { Total } \\
(n=756)\end{array}$ \\
\hline 8 & $30(7 \cdot 6)$ & $34(8 \cdot 7)$ & $64(8 \cdot 2)$ & $31(7 \cdot 8)$ & $21(5 \cdot 9)$ & $52(6 \cdot 9)$ \\
\hline 9 & $82(20 \cdot 7)$ & $74(1$ & $156(19 \cdot 9)$ & $96(24 \cdot 0)$ & $73(20 \cdot 5)$ & $169(22 \cdot 3)$ \\
\hline 11 & $126(31 \cdot 9)$ & $127(32 \cdot 7)$ & $253(32 \cdot 3)$ & $125(31 \cdot 2)$ & $116(32 \cdot 6)$ & $241(31.9)$ \\
\hline $\begin{array}{l}11 \\
12\end{array}$ & $96(24 \cdot 3)$ & $83(21 \cdot 3)$ & $179(22 \cdot 8)$ & $85(21 \cdot 3)$ & $84(23 \cdot 6)$ & $169(22 \cdot 3)$ \\
\hline 12 & $39(9 \cdot 9)$ & $49(12 \cdot 6)$ & $88(11 \cdot 2)$ & $41(10 \cdot 2)$ & $48(13 \cdot 5)$ & $89(11 \cdot 8)$ \\
\hline Mean $(95 \%$ confidence & $\begin{array}{l}22(3.6) \\
10 \cdot 6(10.44 \text { to }\end{array}$ & $\begin{array}{l}22(5 \cdot 7) \\
10.6(10.48 \text { to }\end{array}$ & $\begin{array}{l}44(5 \cdot 6) \\
10 \cdot 6(10 \cdot 50 \text { to }\end{array}$ & 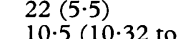 & $14(3.9)$ & $\begin{array}{l}36(4 \cdot 8) \\
10 \cdot 6(10 \cdot 50 \text { to }\end{array}$ \\
\hline $\begin{array}{l}\text { interval) } \\
\text { (n) }\end{array}$ & $10 \cdot 76)$ & $10.72)$ & $10 \cdot 70)$ & $10 \cdot 68)$ & $10 \cdot 72)$ & $10 \cdot 70)$ \\
\hline
\end{tabular}

infants. In addition, eczema, asthma, and wheezy bronchitis, which are closely related, also showed a significantly higher rate in infants born from mothers supplemented with multivitamins in the periconceptional period. These unexpected findings may be a chance effect; however, they need further study.

There was no difference in the postnatal somatic development of infants between the multivitamin and trace element groups. In the UK study at age 7-10 years, girls were taller. ${ }^{8}$ In the Hungarian study, however, girls at about the age of 11 months did not have a greater body length.

The mental and behavioural tests did not show any significant difference in the early postnatal development of infants in the multivitamin and trace element groups. These figures considerably exceed the population average, however, which may be due to the social selection of the HOFPP participants and the optimum periconceptional, prenatal, and postnatal care of their offspring. Our study was not appropriate in confirming or disproving the findings of the UK study - that is, the over representation of worries and anxiety among children at age $7-10$ years. ${ }^{8}$ It is, of course, difficult to study these behavioural traits at 11 months of age. On the other hand, it is possible that the findings were related to maternal anxiety caused by previous pregnancies with neural tube defects.

In conclusion, periconceptional multivitamin supplementation did not appear to affect the postnatal somatic and mental development of infants at the age of 11 months. Data at this early age have poor predictive power for subsequent development, however. Further study of these children is in progress.

We are grateful to the staff of the OFPP (Márta Eröss, Csilla Lehoczky, Zsuzsa Póti, Eva Tökés, Márta Zalatnay, Katalin Sziráki, Adél Técsöi, Borisz Szegal, Gabriella Fritz, István Dudás) and to Dr A Bendich (Roche Vitamins and Fine Dudas) and to Dr A Bendich (Roche Vitamins and Fine
Chemicals, Nutley), Dr R W Smithells (Leeds), and Dr B Chemicals, Nutley), Dr R W Smithells (Leeds), and Dr B
Alleaume (Roche-Nicholas, Geneva) for their help in the revision of the manuscript. We also thank Hoffman-La Roche, Basle and personally thank Dr A Hanck, Dr G Kunovits, and $\mathrm{J}$ Grueter for supplying Elevit Pronatal and trace elements.

1 Smithells RW, Sheppard S, Schorah CJ, et al. Possible prevention of neural tube defects by periconceptional

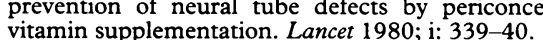

2 Smithells RW, Sheppard S, Wild J, Schorah CJ. Prevention of neural tube defect recurrences in Yorkshire: final report. Lancet 1989; ii: 498-9.

3 Laurence KM, James N, Miller MH, Tennant GB Campbell $\mathrm{H}$. Double-blind randomised controlled tria of folate treatment before conception to preven recurrence of neural-tube defects. $B M \mathcal{F} 1981$; ii $1509-11$.

4 MRC Vitamin Study Research Group. Prevention of neural tube defects: results of the Medical Research Council Vitamin Study. Lancet 1991; 338: 131-7.

5 Czeizel AE, Dudás I. Prevention of the first occurrence of neural-tube defects by periconceptional vitamin suppleneural-tube defects by periconceptional vita
mentation. N Engl f Med 1992; 327: 1832-5.

6 Czeizel AE. Prevention of congenital abnormalities by periconceptional multivitamin supplementation. $B M \mathcal{F} 1993$ 306: $1645-8$.

7 Czzeizel AE, Dudás I, Fritz G, Técsöi A, Hanck A, Kunovits $G$. The effect of multivitamin mineral supplementation on vertigo, nausea and vomiting in the first trimester of pregnancy. Arch Gynecol Obstet 1992; 251: 181-5.

8 Holmes-Siedle M, Dennis J, Lindenbaum RH, Galliard A Long term effects of periconceptional multivitamin supplementation for prevention of neural tube defects: seven to 10 year follow up. Arch Dis Child 1992; 67: $1436-41$.

9 Hegedüs TA, Szondy M, Popper P. Hungarian standard of the development of infants and small children I
(Hungarian). Magyar Pszichologiai Szemle 1975; 32: (Hungarian

10 Hegedüs TA, Szondy M, Popper P. Hungarian standard of the development of infants and small children I (Hungarian). Magyar Pszichologiai Szemle 1975; 32 581-90.

11 Szegal B. Diagnostics of psychomotor development (Hungarian). Magyar Pszichológiai Szemle 1980; 37: 145-62. 